\title{
Optimization of the form of the catalyst intake system in the exhaust system
}

\author{
Optymalizacja kształtu układu dolotowego katalizatora \\ w układzie wydechowym
}

\section{DAWID MROCZKOWSKI MAREK WYLEŻO ${ }^{*}$}

DOI: https://doi.org/10.17814/mechanik.2022.2.2
The goal of the article was to optimize the geometric form of the converter intake system in order to improve the distribution of exhaust gas flow on the surface of the catalyst. The article describes the process of designing the converter inlet cone and the connection pipe, as well as optimizing their shape.

KEYWORDS: converter intake system, catalyst

Celem artykułu była optymalizacja kształtu geometrycznego układu dolotowego konwertera w celu poprawy rozkładu przepływu spalin na powierzchni katalizatora. Opisano proces konstrukcji stożka wlotowego konwertera i rury przyłączeniowej, a także optymalizację ich kształtu.

SŁOWA KLUCZOWE: układ dolotowy konwertera, katalizator

\section{Wprowadzenie}

Opisano proces konstrukcji stożka wlotowego konwertera i rury przyłączeniowej, a także przebieg optymalizacji ich kształtów z myślą o uzyskaniu jak największej równomierności rozkładu prędkości przepływu gazów spalinowych przez katalizator.

Artykuł powstał z potrzeby opracowania i weryfikacji metody numerycznej optymalizacji postaci geometrycznej pod względem wybranych parametrów. Metoda taka pozwoli w przyszłości na przyspieszenie procesu konstruowania wybranych elementów układu wydechowego.

Zaplanowano modernizację hipotetycznego układu wydechowego w zakresie zmiany kształtu stożka wlotowego i rury przyłączeniowej układu oczyszczania spalin samochodu miejskiego. Założono, że stożek wlotowy oraz rura przyłączeniowa będą wykonalne technologicznie i będą spełniały wymogi konstrukcyjne wymagane do poprawnego złożenia elementów oraz będą pasowały do podwozia pojazdu zaimportowanego w postaci modeli CAD (rys. 1).

\section{Założenia konstrukcyjne}

Przed rozpoczęciem prac modelowych przyjęto następujące założenia konstrukcyjne:

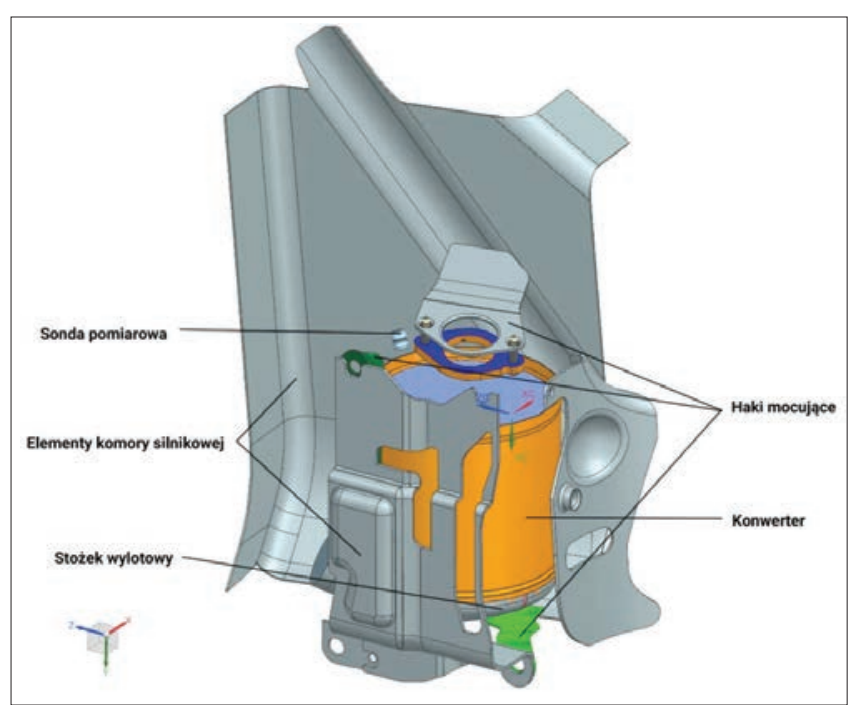

Fig. 1. An example of a catalyst and engine compartment model Rys. 1. Przykładowy model katalizatora oraz komory silnikowej

- część „zimna” układu wydechowego nie będzie modyfikowana, gdyż została w gotowej postaci dostarczona przez klienta,

- wymiary konwerterów oraz ciał porowatych są znormalizowane i nie będą ulegały zmianom,

- należy uwzględnić sposób mocowania układu oraz ograniczenia gabarytowe w komorze silnikowej.

\section{Sformułowanie kryterium optymalizacji}

Podstawowymi kryteriami oceny wariantów kształtu stożka wlotowego i rury przyłączeniowej były współczynnik $\gamma$ oraz wizualna ocena modelowego rozkładu prędkości przepływu spalin dokonywana na płaszczyźnie zdefiniowanej w odległości o 0,015 mm poniżej powierzchni czołowej katalizatora (rys. 2). Współczynnik $\gamma$ jest bezwymiarową wartością wyrażającą powierzchniową równomierność rozkładu prędkości na określonej powierzchni. Celem optymalizacji było uzyskanie równomiernego rozkładu prędkości przepływu spalin na całej powierzchni zdefiniowanej płaszczyzny oraz osiągnięcie jak największej wartości współczynnika $\gamma$.

\footnotetext{
* Mgr inż. Dawid Mroczkowski - dawid96.12mroczkowski@gmail.com, Polska

Dr hab. inż. Marek Wyleżoł - prof. PŚ, marek.wylezol@polsl.pl, https://orcid.org/0000-0001-6324-510X - Katedra Podstaw Konstrukcji Maszyn Wydział Mechaniczny Technologiczny, Politechnika Śląska, Gliwice, Polska
} 


$$
\gamma=1-\frac{\sum_{i=1}^{n} \frac{\sqrt{\left(w_{\mathrm{i}}-\varpi\right)^{2}}}{\varpi} A_{\mathrm{i}}}{2 \eta A}
$$

gdzie:

y - współczynnik jednorodności rozkładu przepływu, $w_{\mathrm{i}}$ - prędkość przepływu dla pojedynczej komórki,

$\varpi$ - średnia prędkość przepływu,

$A_{\mathrm{i}}$ - pole dla pojedynczej komórki,

$\eta$ - liczba komórek,

A - pole.

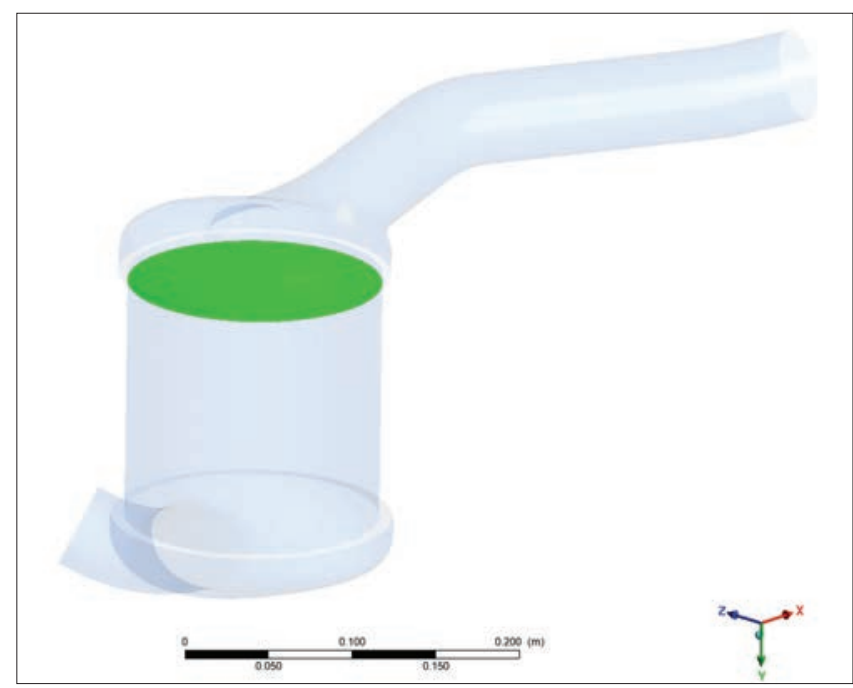

Fig. 2. The gamma parameter observation area Rys. 2. Obszar obserwacji parametru gamma

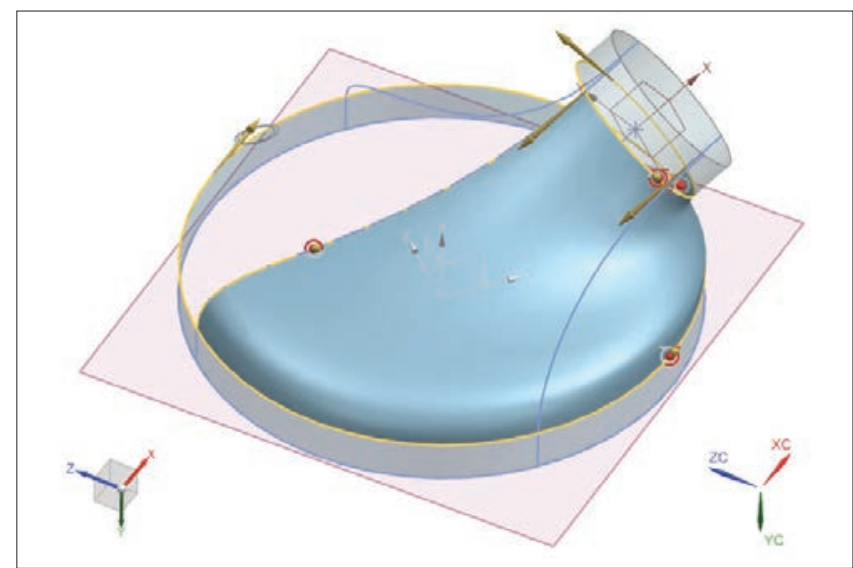

Fig. 3. The first method of the inlet cone modeling Rys. 3. Pierwsza metoda modelowania stożka wlotowego

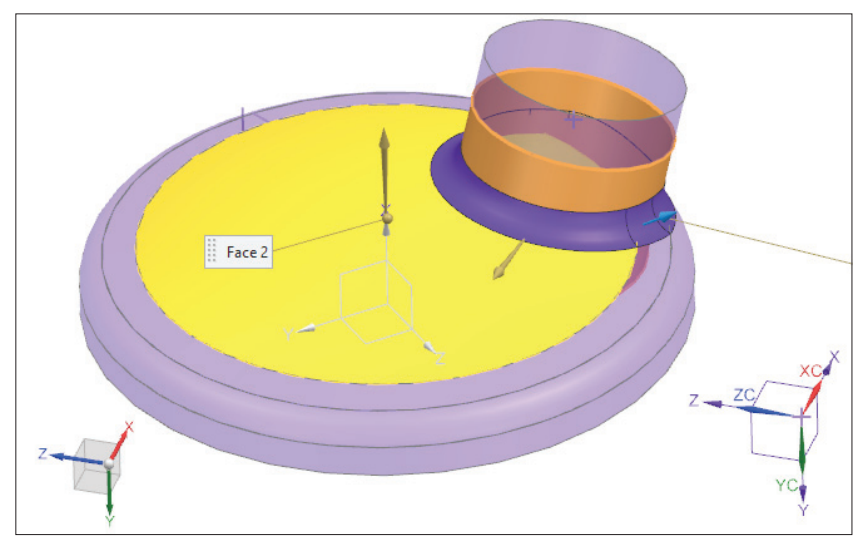

Fig. 4. The second method of the inlet cone modeling Rys. 4. Druga metoda modelowania stożka wlotowego
Na początku (metoda nr 1) utworzono pierwszy model stożka wlotowego i rury przyłączeniowej, a następnie przygotowano model klasy CFD uwzględniający katalizator i stożek wylotowy za katalizatorem. Pierwsze modele stożka wlotowego utworzono z zastosowaniem funkcji Through Curve Mesh systemu Siemens NX (rys. 3), która tworzy powierzchnie na podstawie zdefiniowanych krzywych. Kolejny model (metoda $\mathrm{nr}$ 2) utworzono z wykorzystaniem operacji Fill Surface (kolor żółty) oraz Face Blend (kolor fioletowy, rys. 4). Pierwsza operacja tworzy powierzchnie o styczności w klasie G1 względem otaczających ją powierzchni, natomiast druga definiuje zaokrąglenie o określonym promieniu pomiędzy wlotem a główną częścią stożka wlotowego. Wartość promienia zaokrąglenia będzie miała wpływ na strugę przepływających spalin - w tym przypadku mniejszy promień zaokrąglenia powoduje szybsze oderwanie się strugi spalin w kierunku katalizatora, natomiast większy promień sprawia, że struga dłużej przylega do górnej części stożka. Zbyt duży promień zaokrąglenia powoduje skupienie się przepływających spalin na ścianie naprzeciw wlotu, a w przypadku zbyt małego promienia - zaraz przy wlocie.

\section{Dyskretyzacja modelu}

$\mathrm{Na}$ kolejnym etapie postępowania przygotowano model CFD, który został zdyskretyzowany za pomocą elementów skończonych 2. rzędu. Do katalizatora i stożka wylotowego zastosowano elementy skończone o największej długości boku równej $6 \mathrm{~mm}$, przy włączonej opcji Defeature Size, która dopuszcza wygenerowanie najmniejszego elementu skończonego o boku $5 \mathrm{~mm}$. Natomiast wobec stożka wlotowego - w celu uzyskania dokładniejszego przepływu - zastosowano operację Body Sizing zmniejszającą zdefiniowaną największą długość boku elementu skończonego do 3,25 mm przy aktywnej opcji Defeature Size z wprowadzoną wartością $3 \mathrm{~mm}$. Następnie zdefiniowano sekcje wlotu i wylotu gazów spalinowych, które zostały później użyte w symulacji (rys. 5).

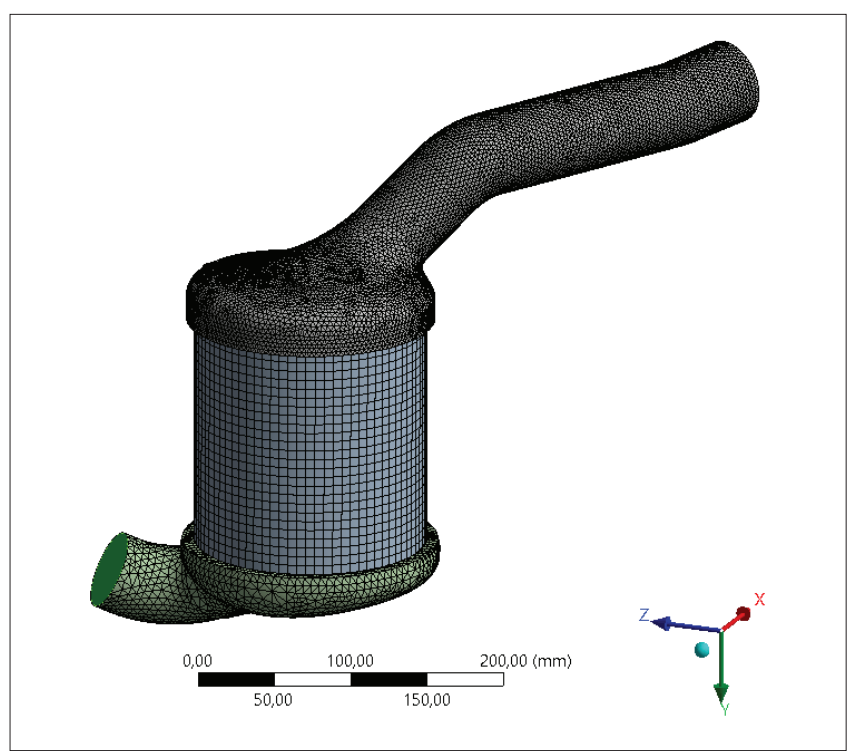

Fig. 5. Discretization of the model Rys. 5. Dyskretyzacja modelu 


\section{Zdefiniowanie warunków brzegowych}

Na potrzeby przeprowadzenia symulacji przepływu spalin zdefiniowano przyspieszenie ziemskie równe $9,81 \mathrm{~m} / \mathrm{s}^{2}$ o zwrocie przeciwnym do wektora $Z$. Zastosowano model turbulencji $k-\omega S S T$, który modeluje efekty przyścienne $\mathrm{w}$ ramach modelu $k-\omega$, a także modeluje obszary swobodnego mieszania w ramach modelu $k-\varepsilon$ oraz modeluje przejścia laminarno-turbulentne. Do zdefiniowania spalin użyto gazu importowanego z bazy predefiniowanych płynów w systemie ANSYS - carbon-oxide-nitride o gęstości i lepkości $4,07 \mathrm{e} \cdot 10^{5} \frac{\mathrm{kg}}{\mathrm{m}} \cdot \mathrm{s}$, co odpowiada gęstości spalin w temperaturze $700^{\circ} \mathrm{C}$.

Dla katalizatora zdefiniowano dodatkowo porowatość i przepływ laminarny. Nadano właściwość ciała porowatego o oporze lepkości równej $3,48 \mathrm{e} \cdot 10^{7} \mathrm{l} / \mathrm{m}^{2}$ w kierunku osi katalizatora i $3,48 \mathrm{e} \cdot 10^{10} \mathrm{l} / \mathrm{m}^{2} \mathrm{w}$ pozostałych kierunkach oraz opór inercji równy $54,3 \mathrm{l} / \mathrm{m}$ (dane literaturowe). Na wlocie układu przypisano literaturowy profil prędkości (rys. 6) oraz ciśnienie równe 24500 Pa. Natomiast do wylotu przypisano przeciwciśnienie $18500 \mathrm{~Pa}$. Symulację przepływu przeprowadzono, ustawiając liczbę iteracji równą 1000.

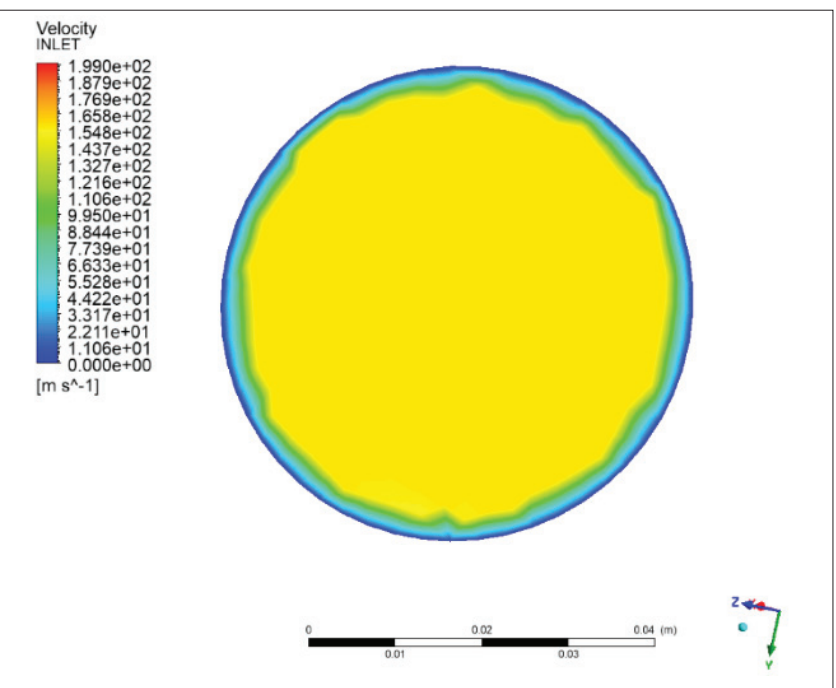

Fig. 6. Applied speed profile

Rys. 6. Zastosowany profil prędkości

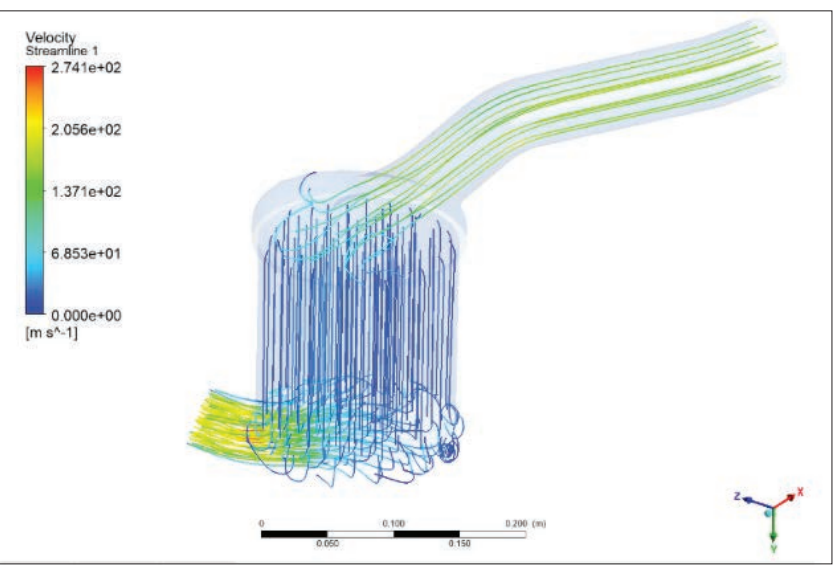

Fig. 7. Flow patterns for the first variant of the inlet cone and the connection pipe

Rys. 7. Strugi przepływu dla pierwszego wariantu stożka wlotowego i rury przyłączeniowej

\section{Wyniki analizy wszystkich pięciu wariantów rury przyłączeniowej i stożka wlotowego}

Na rys. 8-12 zestawiono wyniki symulacji dla wszystkich wariantów. Kolejne warianty ulegały zmianom geometrii w celu poprawy rozkładu prędkości na powierzchni katalizatora oraz uzyskania większej wartości współczynnika $y$.

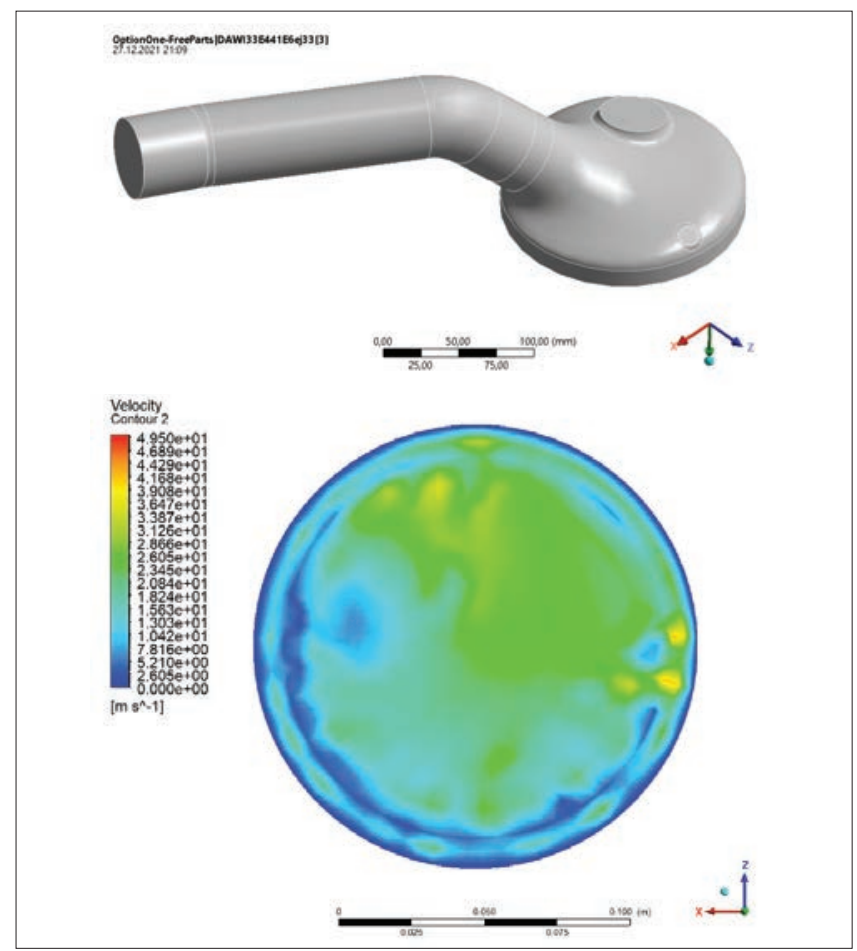

Fig. 8. The first variant and the flow velocity distribution on the catalyst surface

Rys. 8. Pierwszy wariant i rozkład prędkości przepływu na powierzchni katalizatora

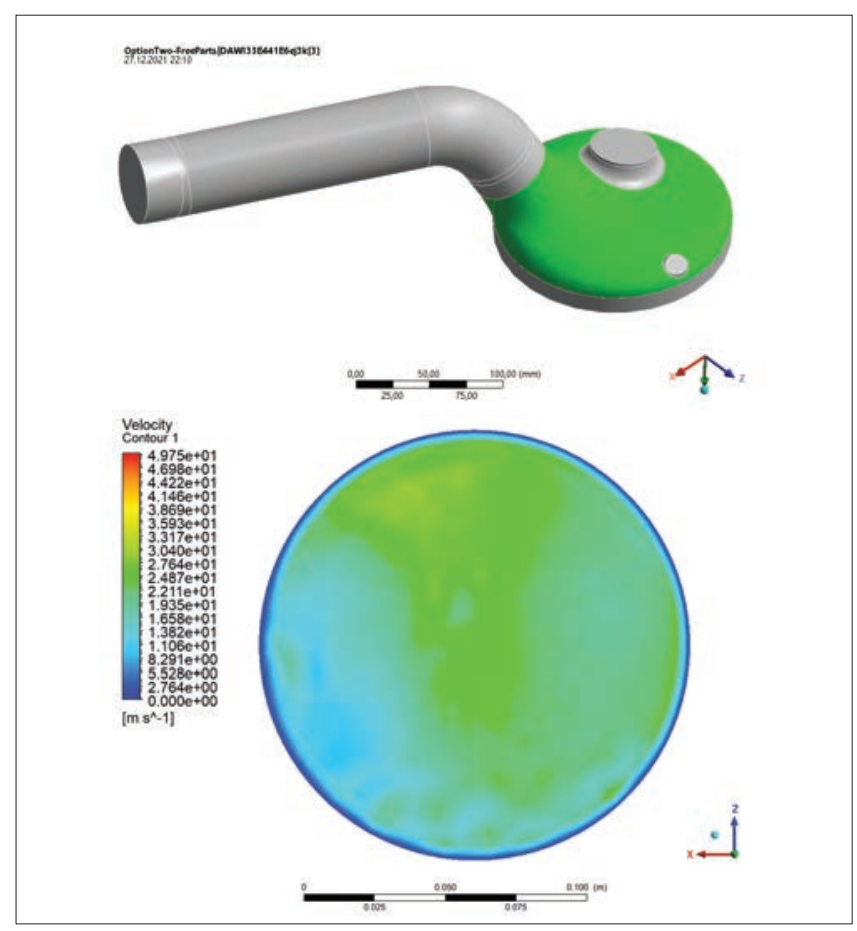

Fig. 9. The second variant and the flow velocity distribution on the catalyst surface

Rys. 9. Drugi wariant i rozkład prędkości przepływu na powierzchni katalizatora 


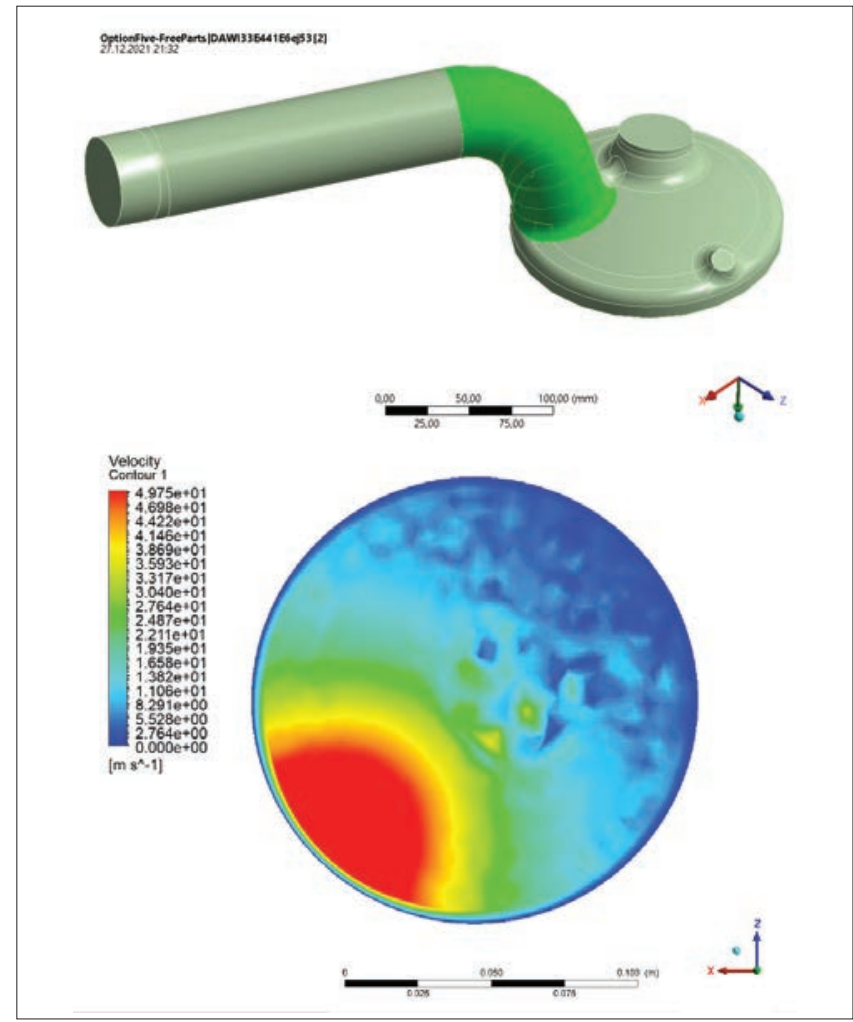

Fig. 10. The third variant and the flow velocity distribution on the catalyst surface

Rys. 10. Trzeci wariant i rozkład prędkości przepływu na powierzchn katalizatora

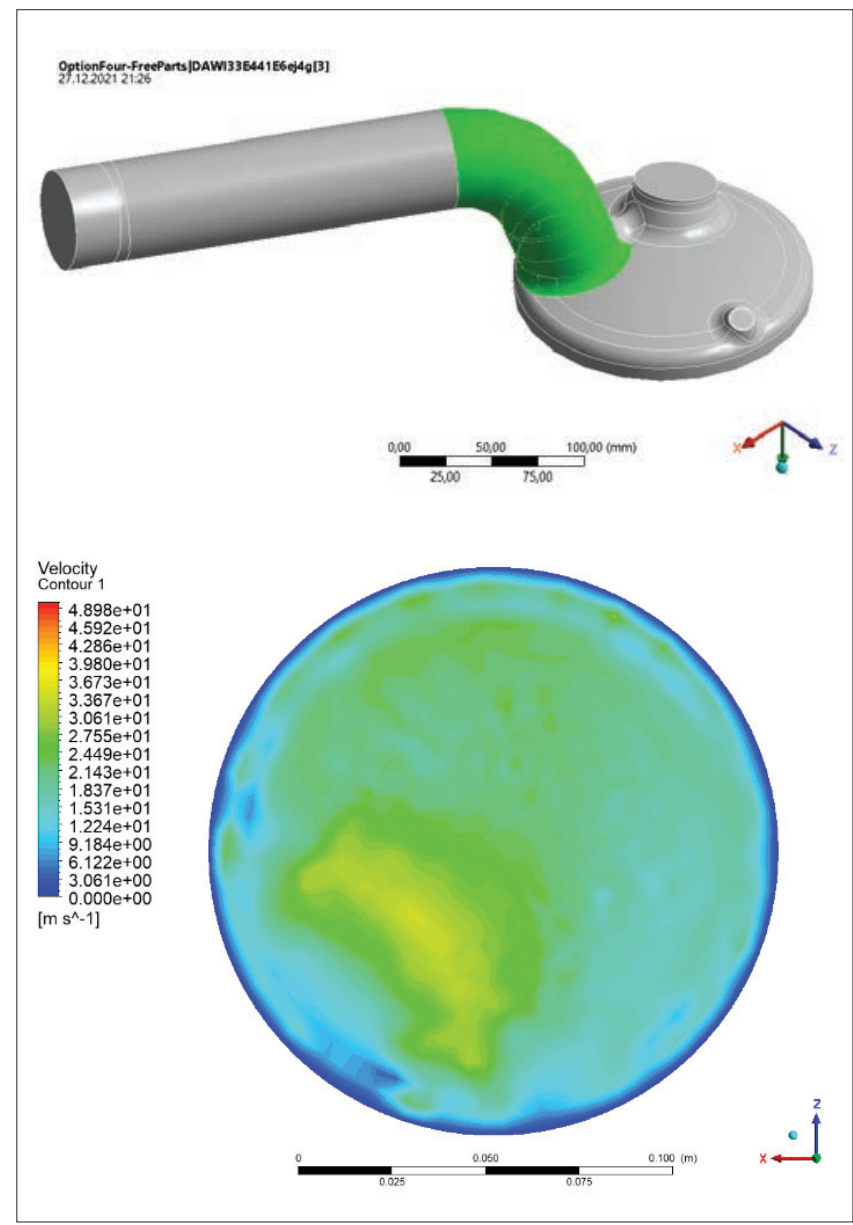

Fig. 11. The fourth variant and the flow velocity distribution on the catalyst surface

Rys. 11. Czwarty wariant i rozkład prędkości przepływu na powierzchni katalizatora
W kolejnym wariancie w celu uniknięcia skupienia strugi płynu na ścianie przeciwległej do wlotu katalizatora zmniejszono kąt pomiędzy osiami katalizatora i osią wlotu.

W celu dalszego zwiększenia równomierności rozkładu prędkości przepływu kolejny wariant stożka zamodelowano w drugi, wspomniany sposób, co jeszcze bardziej zmniejszyło kąt pomiędzy osiami, ponadto zmniejszono promień zaokrąglenia przedstawionego kolorem fioletowym (rys. 4). W tym przypadku jednak struga spalin zbyt mocno koncentrowała się przy wlocie do katalizatora, co przyniosło skutek odwrotny do oczekiwanego.

W celu zwiększenia równomierności rozkładu prędkości w kolejnym wariancie zwiększono kąt pomiędzy osią katalizatora a osią wlotu, a także stopniowo zwiększano promień zaokrąglenia.

W czwartym wariancie struga płynu osiągnęła mniejszą prędkość, odsunęła się wyraźnie od ścianki katalizatora, a w pozostałej części charakteryzowała się równomiernością rozkładu prędkości spalin. W celu dalszego zwiększenia jednorodności przepływu ponownie zwiększono kąt pomiędzy osią katalizatora a osią wlotu.

W ostatnim wariancie osiągnięto największą wstępną wartość współczynnika $\gamma$. Wariant ten został użyty do optymalizacji kształtu, która została opisana w dalszej części artykułu.

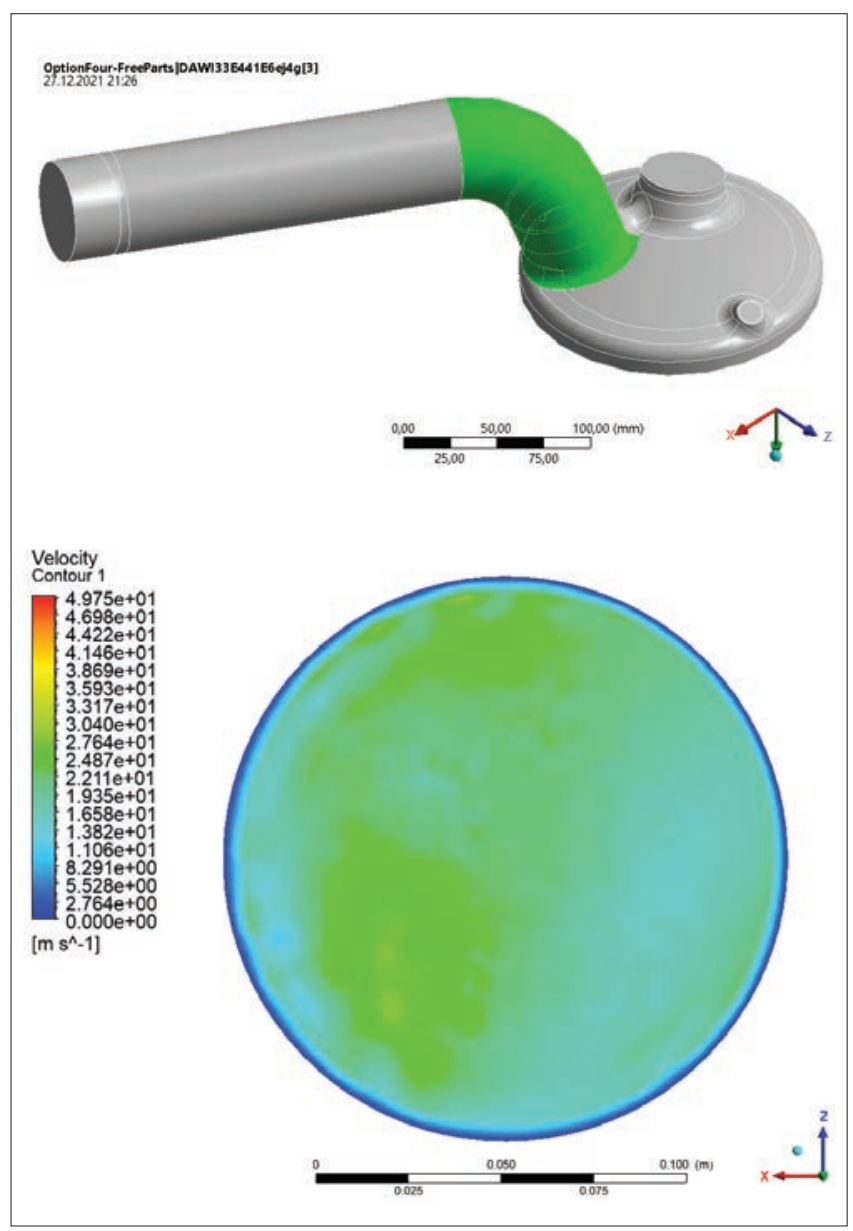

Fig. 12. The fifth variant and the flow velocity distribution on the catalyst surface

Rys. 12. Piąty wariant i rozkład prędkości przepływu na powierzchni katalizatora 


\section{Wykorzystanie solvera Adjoint do optymalizacji kształtu stożka wlotowego i rury przyłączeniowej}

W celu poprawy równomierności rozkładu przepływu spalin zastosowano moduł Adjoint Solver służący do optymalizacji wybranych parametrów. W module tym definiuje się obserwowane przez solver parametry i decyduje, czy dane wartości mają być minimalizowane czy maksymalizowane na określonej powierzchni lub objętości.

W tym przypadku celem optymalizacji była minimalizacja wartości wektora prędkości przepływu spalin w osi $Y$. Wartość wektora była obserwowana we wcześniej zdefiniowanej płaszczyźnie. Uzyskanie mniejszej wartości wektora prędkości spalin wiąże się $\mathrm{z}$ brakiem skupienia przepływu $\mathrm{w}$ danych miejscach, co z kolei jest równoważne ze zwiększeniem równomierności rozkładu przepływu strugi spalin.

W pierwszym kroku zdefiniowano obszar, w obrębie którego miał być obserwowany dany wektor. Następnie wyodrębniono geometrię, przeznaczoną do modyfikowana przez solver w celu uzyskania optymalnej wartości obserwowanego parametru na wylocie. W kolejnym kroku postępowania zaimportowano płat powierzchni reprezentowany w formacie STL (rys. 14), który modeluje ograniczenie gabarytowe rury przyłączeniowej. Powierzchnia ta to jednocześnie granica zapewniająca $10 \mathrm{~mm}$ odstępu pomiędzy rurą przyłączeniową a jednym z elementów składowych haka mocującego. Solver - modyfikując daną geometrię - uwzględnia tego rodzaju wskazane ograniczenie (jako warunek brzegowy) $w$ postaci zaimportowanego płata powierzchni.

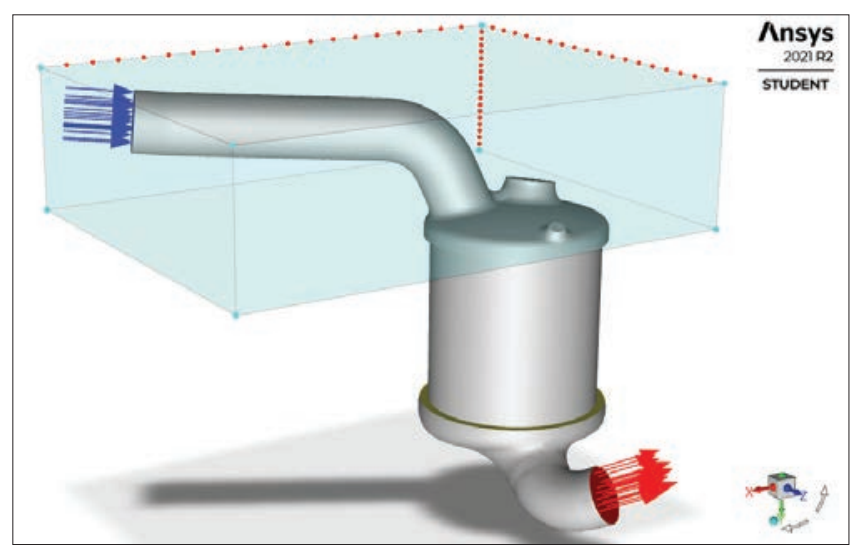

Fig. 13. Defining the area within which the geometry will be modified

Rys. 13. Zdefiniowanie obszaru, w obrębie którego będzie zmodyfikowana geometria

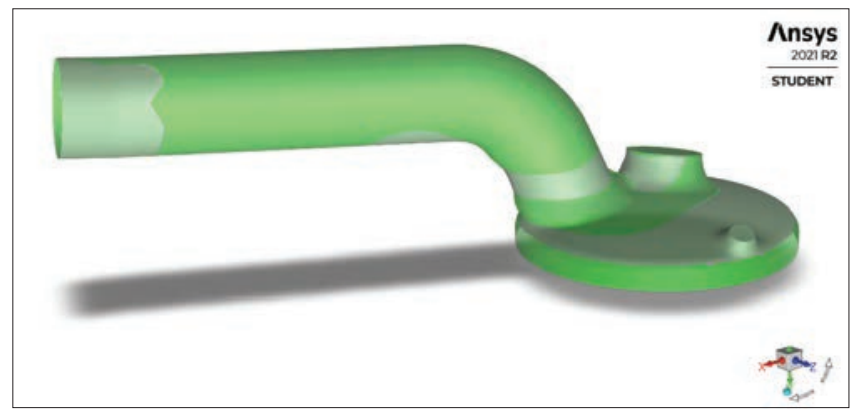

Fig. 14. Resulting geometry after the simulation Rys. 14. Wynikowa geometria po przeprowadzeniu symulacji

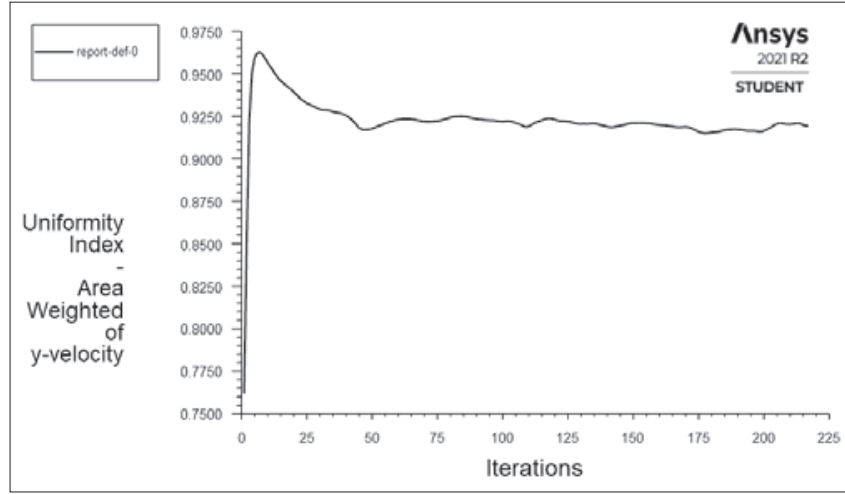

Fig. 15. Graph showing the change in the value of the coefficient $\gamma$ during the simulation

Rys. 15. Wykres przedstawiający zmianę wartości współczynnika $\gamma$ w trakcie symulacji

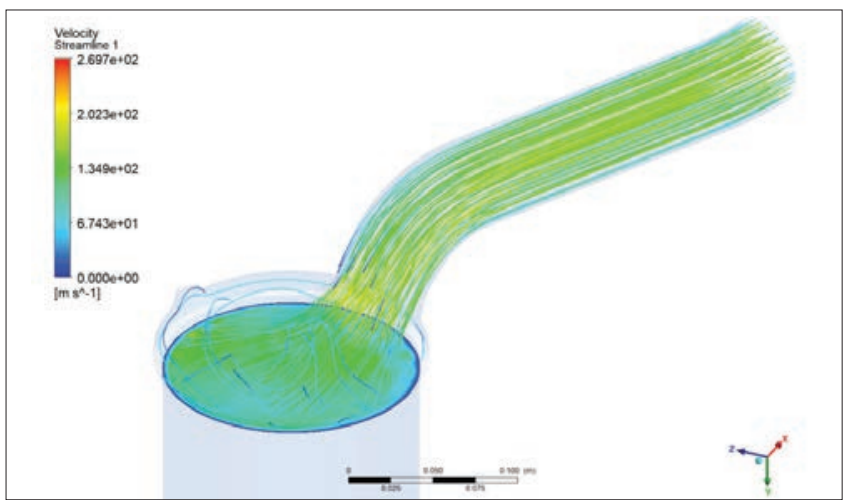

Fig. 16. Flue gas flow pattern for an optimized shape of the inlet cone and the connection pipe

Rys. 16. Struga przepływu spalin dla zoptymalizowanego kształtu stożka wlotowego i rury przyłączeniowej

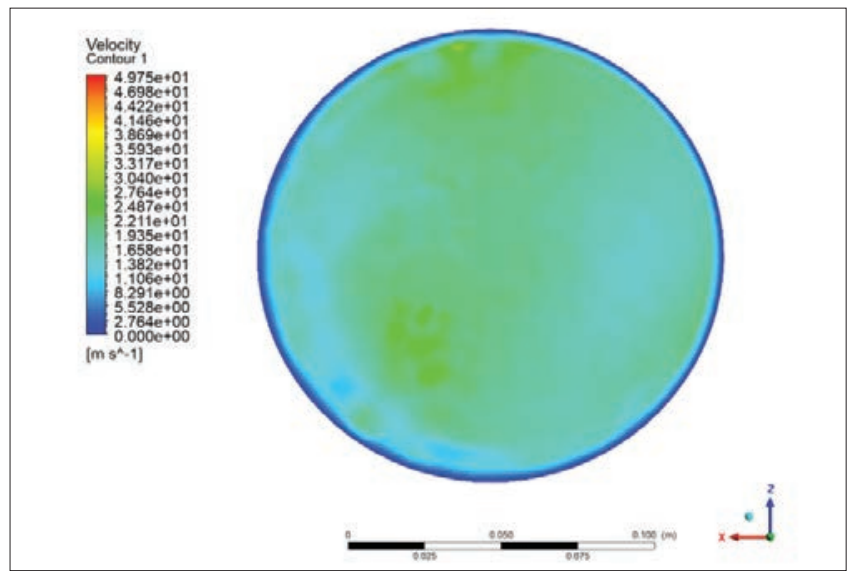

Fig. 17. Distribution of exhaust gas velocity on a defined plane Rys. 17. Rozkład prędkości spalin na zdefiniowanej płaszczyźnie

Wynikiem symulacji były:

1) postaci geometryczne stożka wlotowego i rury przyłączeniowej, dla których przeprowadzono ponowną symulację CFD (rys. 14) w celu ich weryfikacji, 2) plik STL, który zaimportowano do oprogramowania NX i zinterpretowano w taki sposób, aby dane elementy były również wykonalne.

Po przeprowadzeniu optymalizacji uzyskano większą jednorodność rozkładu prędkości przepływu spalin oraz większą wartość współczynnika $\gamma$. Na rys. 18 przedstawiono wartości współczynnika $\gamma$ dla wszystkich wariantów rury przyłączeniowej i stożka wlotowego. 


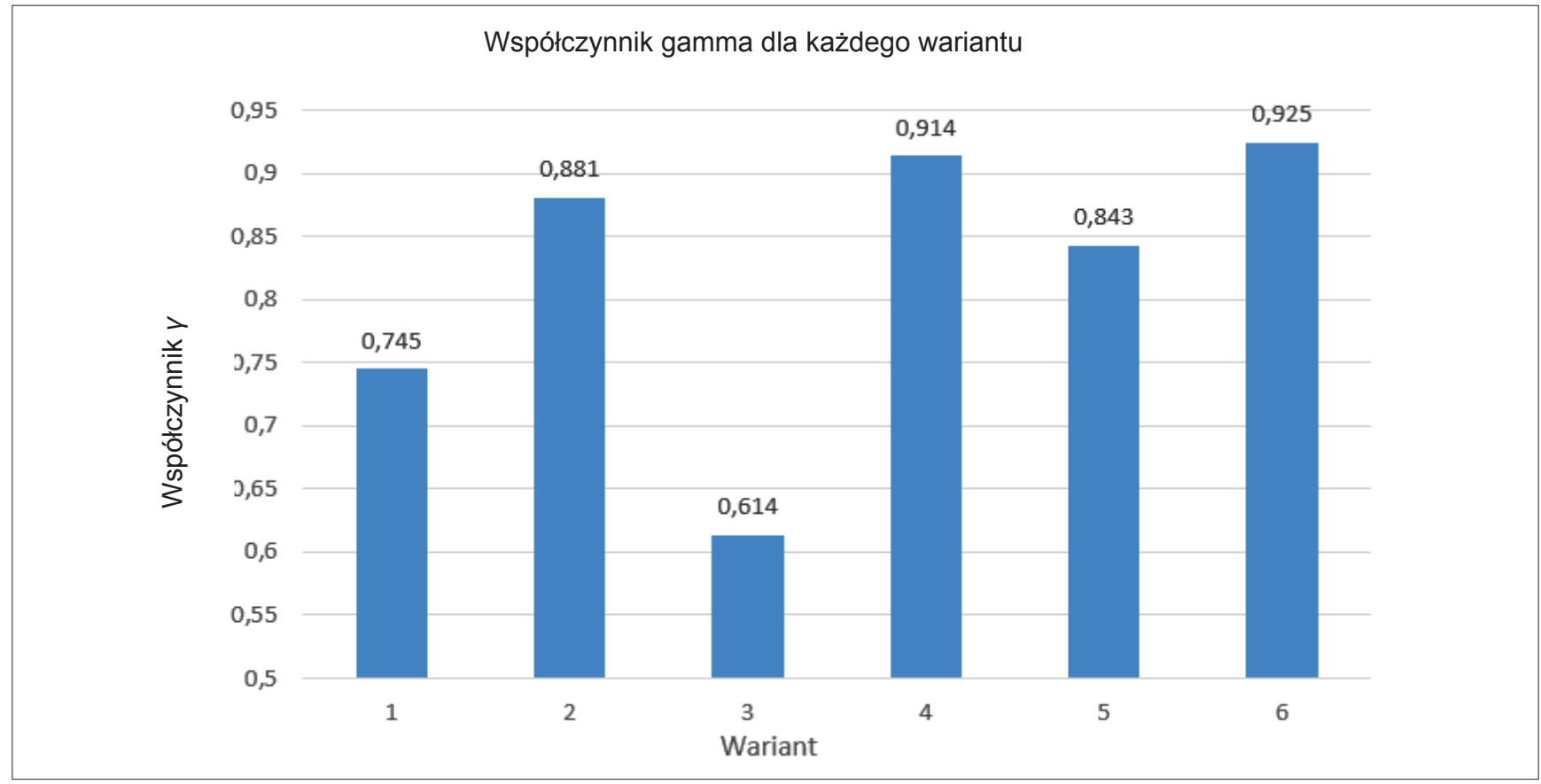

Fig. 18. Graph showing the value of the $\gamma$ coefficient for each variant

Rys. 18. Wykres przedstawiający wartość współczynnika $\gamma$ dla każdego wariantu

\section{Interpretacja geometrii STL z oprogramowania ANSYS}

Porównując bazową geometrię i geometrię zaimportowaną (ograniczający płat powierzchni), można zauważyć, że modyfikacja przeprowadzona przez sol-

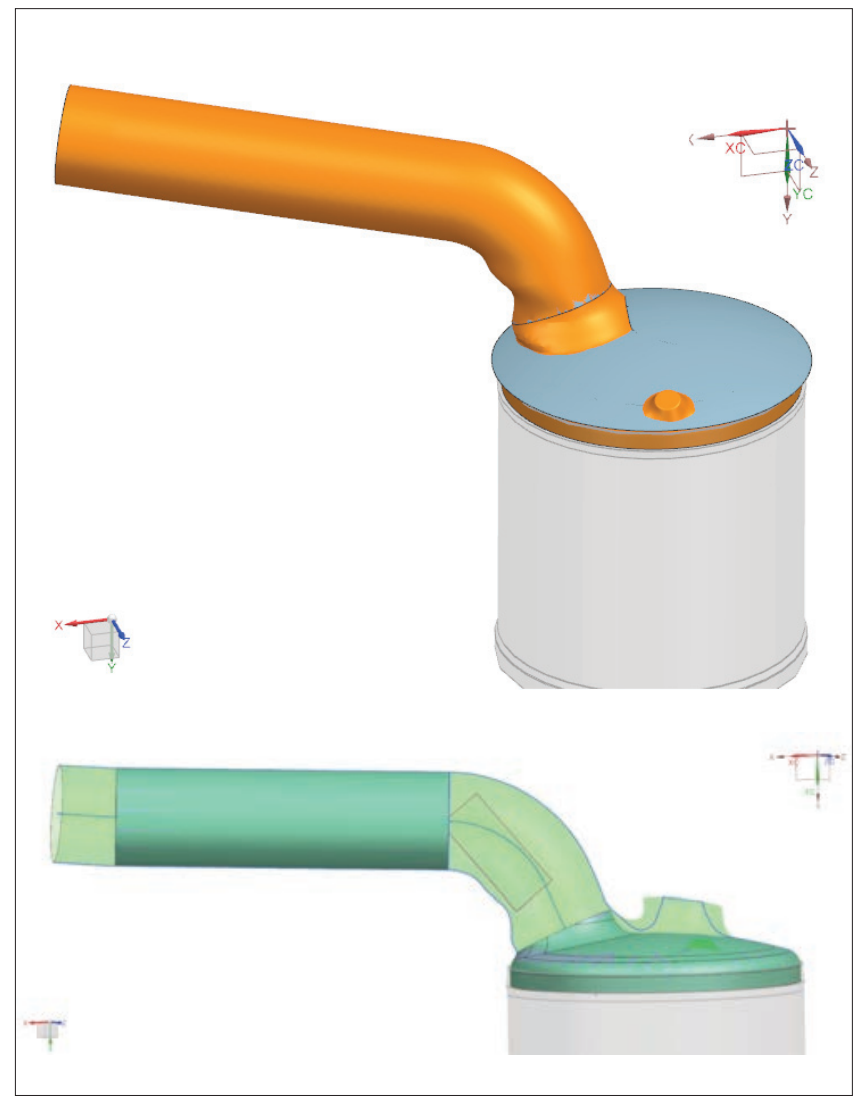

Fig. 19. Importing the limiting lobe as STL geometry and modeling the crease

Rys. 19. Importowanie płata ograniczającego jako geometrii STL oraz modelowanie przetłoczenia ver ANSYS polegała głównie na wygenerowaniu wtłoczenia na końcu rury przyłączeniowej (rys. 19).

Następnie wykonano modele powierzchniowe rury przyłączeniowej i połówek stożka wlotowego na podstawie zaimportowanej geometrii. Ostatnim etapem opracowywania konstrukcji była analiza tłoczności

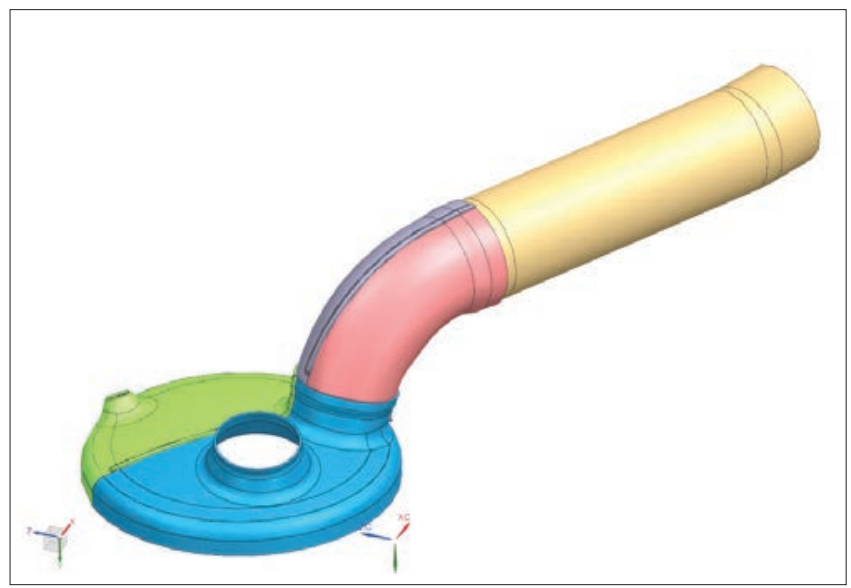

Fig. 20. Final models of the inlet cone and connection pipe Rys. 20. Finalne modele stożka wlotowego i rury przyłączeniowej

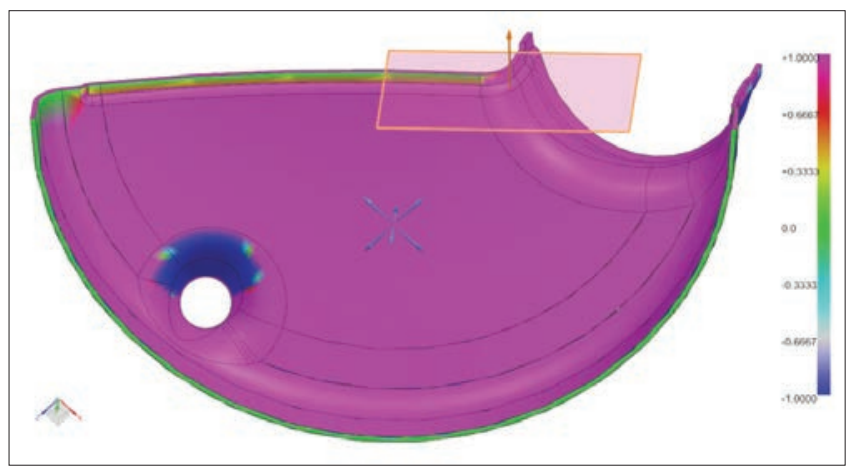

Fig. 21. Compression analysis of the first half of the inlet cone Rys. 21. Analiza tłoczności pierwszej połówki stożka wlotowego 


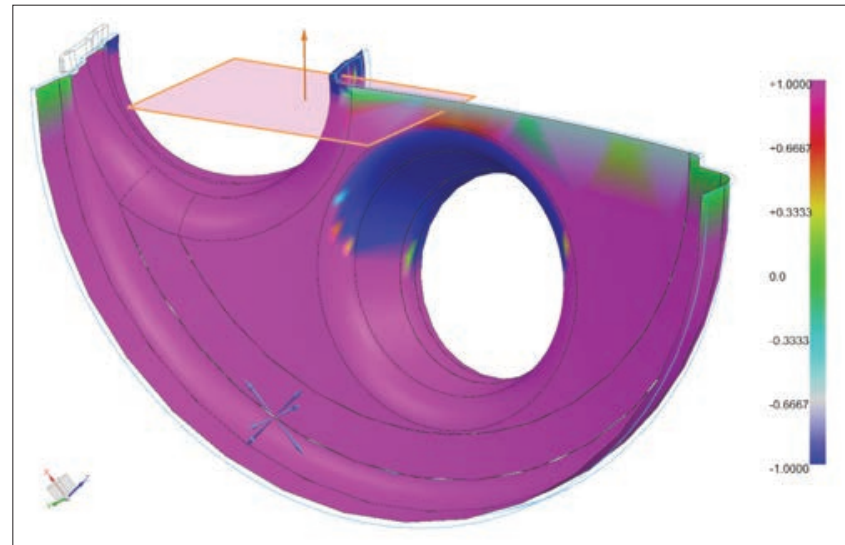

Fig. 22. Compressibility analysis of the second half of the inlet cone Rys. 22. Analiza tłoczności drugiej połówki stożka wlotowego

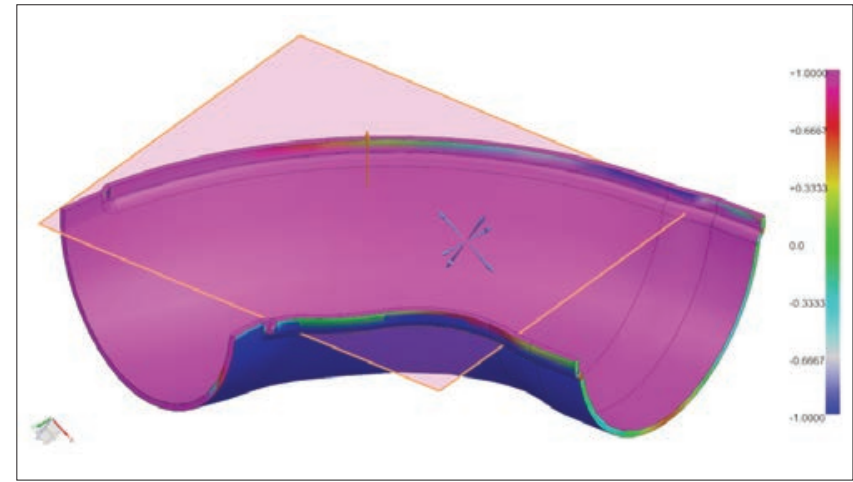

Fig. 23. Compressibility analysis of the first half of the connection pipe end

Rys. 23. Analiza tłoczności pierwszej połówki końcówki rury przyłączeniowej

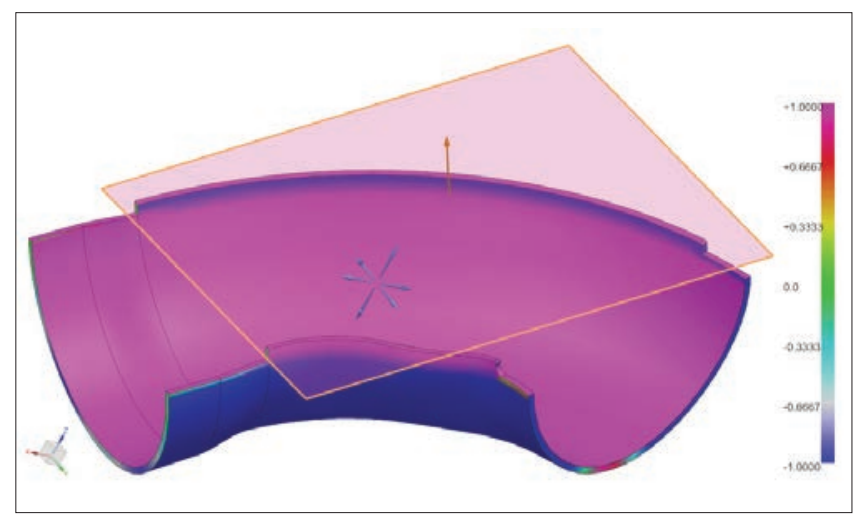

Fig. 24. Compressibility analysis of the second half of the connection pipe end

Rys. 24. Analiza tłoczności drugiej połówki końcówki rury przyłączeniowej

połówek stożka wlotowego i wyodrębnionej części rury przyłączeniowej, aby się upewnić, czy tak skonstruowane elementy będą technologiczne w kontekście ich wytworzenia za pomocą technologii tłoczenia.

Proces wytwarzania stożka wlotowego ma dwa etapy. Na pierwszym etapie tłoczony jest główny kształt stożka wlotowego, a kierunkiem tłoczenia każdej połówki jest wektor normalny płaszczyzny podziału stożka przedstawiony na rys.21-24. Otwory znajdujące się na połówkach stożka wlotowego tłoczone są w osobnych operacjach, dlatego w ich przypadku dopuszczalna jest ujemna wartość nachylenia powierzchni w danej analizie.

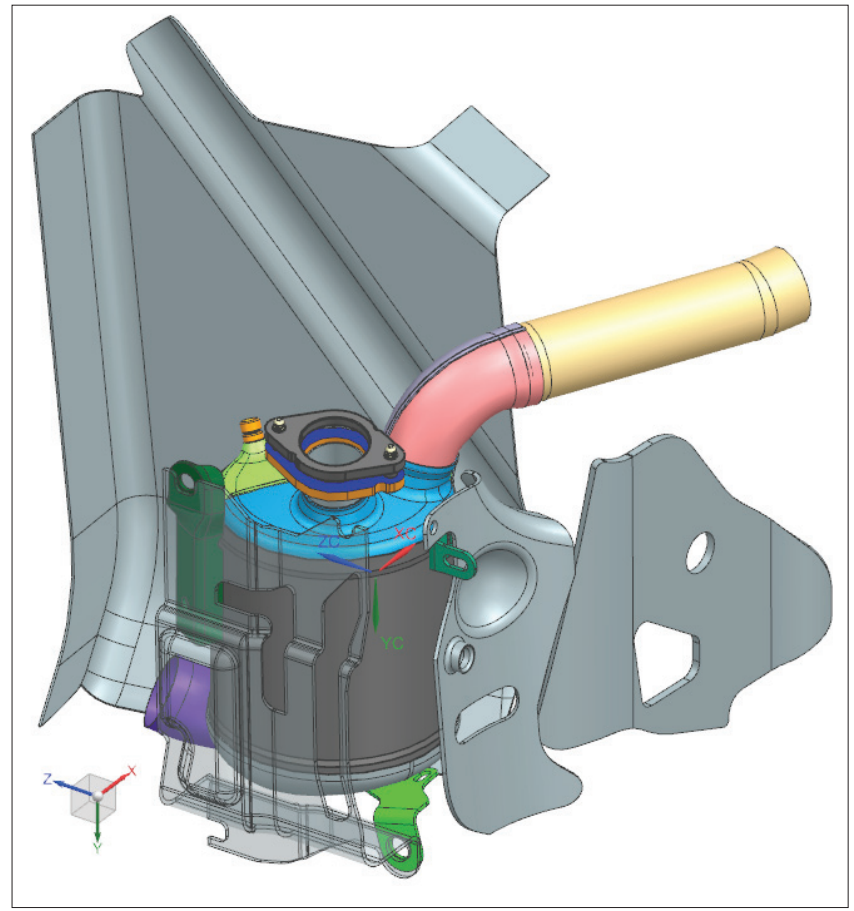

Fig. 25. Assembly of new models and other geometries Rys. 25. Złożenie nowych modeli i pozostałych geometrii

Analiza tłoczności wskazała, że modele stożka wlotowego i końcówki rury przyłączeniowej są technologicznie tłoczne. Na krawędziach połówek nachylenie zbliża się do $0^{\circ}$, co w takich miejscach jest dopuszczalne.

\section{Podsumowanie}

1) Na podstawie przeprowadzonej optymalizacji hipotetycznej konstrukcji stożka wlotowego i rury przyłączeniowej udało się zaprojektować kształt stożka wlotowego i rury przyłączeniowej, które zapewniają wysoką jednorodność przepływu spalin przez powierzchnie katalizatora.

2) Uzyskano największą wartość współczynnika y równą 0,925 .

3) Wysoką wartość współczynnika rozkładu otrzymano dzięki modyfikacji kształtu stożka dolotowego oraz rury przyłączeniowej, z zachowaniem ograniczeń gabarytowych oraz normalizacji komponentów.

4) Podczas symulacji wykorzystano uproszczony model klasy CAD, co mogło się przyczynić do pewnych niedokładności obliczeń numerycznych.

\section{LITERATURA}

[1] "Introduction to ANSYS FLUENT", https://imechanica. org/files/fluent_13.0_lecture02-intro-to-cfd.pdf (dostęp: 29.12.2021).

[2] Jeżowiecka-Kabsch K., Szewczyk H. „Mechanika płynów”. Wrocław: Oficyna Wydawnicza Politechniki Wrocławskiej, 2001.

[3] "Numerical investigation of SCR mixer design optimization for improved performance", https://www.mdpi.com/22279717/7/3/168/htm (dostęp: 29.12.2021).

[4] Pawłucki M., Kryś M. „CFD dla inżynierów Praktyczne ćwiczenia na przykładzie systemu ANSYS Fluent”. Gliwice: Helion SA, 2020. 